\title{
Traces of the crustal units and the upper-mantle structure in the southwestern part of the East European Craton
}

\author{
I. Janutyte ${ }^{1,2}$, E. Kozlovskaya ${ }^{3}$, M. Majdanski ${ }^{4}$, P. H. Voss $^{5}$, M. Budraitis $^{6}$, and PASSEQ Working Group ${ }^{7}$ \\ ${ }^{1}$ NORSAR, Kjeller, Norway \\ ${ }^{2}$ Vilnius University, Vilnius, Lithuania \\ ${ }^{3}$ Sodankylä Geophysical Observatory/Oulu Unit, University of Oulu, Oulu, Finland \\ ${ }^{4}$ Institute of Geophysics, Polish Academy of Sciences, Warsaw, Poland \\ ${ }^{5}$ Geological Survey of Denmark and Greenland - GEUS, Copenhagen, Denmark \\ ${ }^{6}$ GEOBALTIC, Vilnius, Lithuania \\ ${ }^{7}$ Indicated in Acknowledgements \\ Correspondence to: I. Janutyte (ilma@norsar.no)
}

Received: 25 March 2014 - Published in Solid Earth Discuss.: 8 April 2014

Revised: 29 June 2014 - Accepted: 4 July 2014 - Published: 15 August 2014

\begin{abstract}
The presented study is a part of the passive seismic experiment PASSEQ 2006-2008, which took place around the Trans-European Suture Zone (TESZ) from May 2006 to June 2008. The data set of 4195 manually picked arrivals of teleseismic $P$ waves of 101 earthquakes (EQs) recorded in the seismic stations deployed to the east of the TESZ was inverted using the non-linear teleseismic tomography algorithm TELINV. Two 3-D crustal models were used to estimate the crustal travel time (TT) corrections. As a result, we obtain a model of $P$-wave velocity variations in the upper mantle beneath the TESZ and the East European Craton (EEC). In the study area beneath the craton, we observe up to $3 \%$ higher and beneath the TESZ about 2-3\% lower seismic velocities compared to the IASP91 velocity model. We find the seismic lithosphere-asthenosphere boundary (LAB) beneath the TESZ at a depth of about $180 \mathrm{~km}$, while we observe no seismic LAB beneath the EEC. The inversion results obtained with the real and the synthetic data sets indicate a ramp shape of the LAB in the northern TESZ, where we observe values of seismic velocities close to those of the craton down to about $150 \mathrm{~km}$. The lithosphere thickness in the EEC increases going from the TESZ to the NE from about $180 \mathrm{~km}$ beneath Poland to $300 \mathrm{~km}$ or more beneath Lithuania. Moreover, in western Lithuania we find an indication of an uppermantle dome. In our results, the crustal units are not well resolved. There are no clear indications of the features in the upper mantle which could be related to the crustal units in the
\end{abstract}

study area. On the other hand, at a depth of $120-150 \mathrm{~km}$ we indicate a trace of a boundary of proposed palaeosubduction zone between the East Lithuanian Domain (EL) and the West Lithuanian Granulite Domain (WLG). Also, in our results, we may have identified two anorogenic granitoid plutons.

\section{Introduction}

The East European Craton (EEC) (Fig. 1), the palaeocontinent Baltica, has not been tectonically reworked for at least $1.45 \mathrm{Ga}$ (Bogdanova et al., 2006). The EEC includes a mosaic of tectonic structures. It has formed during the collision of three palaeocontinents: Sarmatia, Volgo-Uralia and Fennoscandia 2-1.7 Ga (Bogdanova et al., 2001; Artemieva, 2007). The EEC in the east is bordered by the Uralides orogen and the Timan Ridge, and in the west by the TransEuropean Suture Zone (TESZ), the boundary between Proterozoic Eastern Europe and Phanerozoic western-central Europe (Nolet and Zielhuis, 1994). The inner major sutures in the EEC are the Central Russia Rift System and the Pachelma Rift, which mark amalgation of Baltica in the north, Sarmatia in the west and Volgo-Uralia in the east during the Proterozoic Period (Gorbatschev and Bogdanova, 1993). During a long evolution, the EEC resulted in a complex structure of the crust and the upper mantle, which were intensively investigated during a number of studies (e.g. 


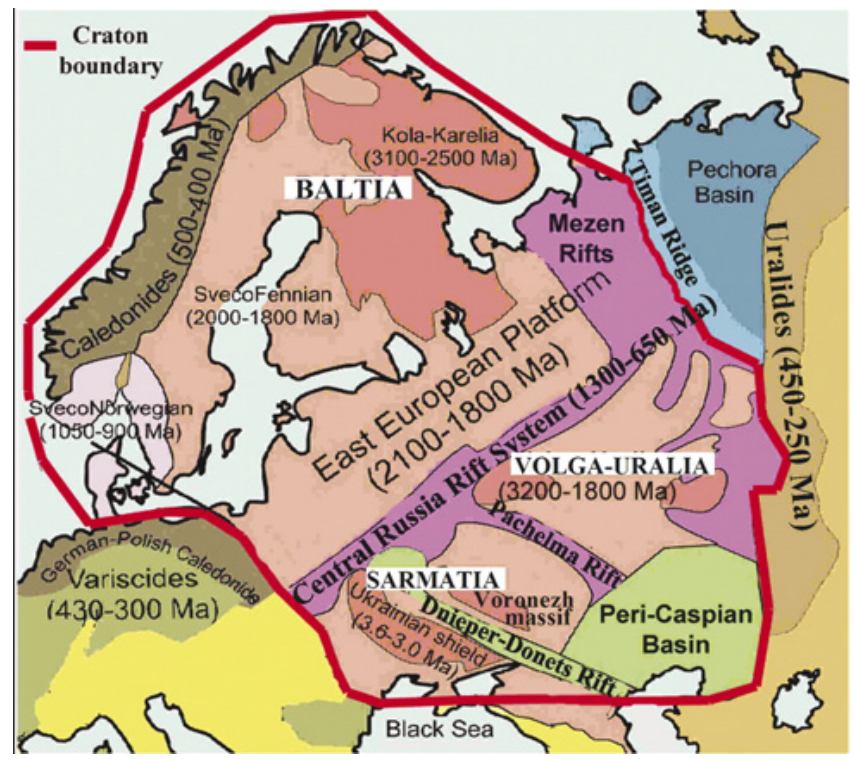

Figure 1. Tectonic settings of the EEC (after Artemieva et al., 2006).

Guterch et al., 1999, 2004; Grad et al., 2006; EUROBRIDGE Seismic Working Group, 1999; Pharaoh et al., 2000; WildePiórko et al., 2010; Knapmeyer-Endrun et al., 2013).

Our study is focused on the SW part of the EEC. The study area covers the NW part of the territory of the passive seismic experiment PASSEQ 2006-2008 (Wilde-Piórko et al., 2008), which was carried out around the TESZ in order to study the lithosphere and asthenosphere beneath the area. The aims of our study are to define (1) whether there is a correlation between the crustal units and the upper mantle, and (2) to estimate the seismic $P$-wave velocity structure of the upper mantle and the lithosphere thickness beneath the study area using the data acquired during the PASSEQ 2006-2008 project and the method of non-linear teleseismic tomography.

\section{Crust and lithosphere structure}

The deep seismic sounding (DSS) projects - such as EUROBRIDGE (EUROBRIDGE Seismic Working Group, 1999), POLONAISE'97 (Guterch et al., 1999), CELEBRATION 2000 (Malinowski et al., 2008), etc. (Fig. 2), carried out around the TESZ in the SW part of the EEC - provided crucial information about the crustal and upper-mantle structure in the area to the depth of about $80 \mathrm{~km}$. The structure of the upper mantle extending to several hundreds of kilometres has been modelled during other studies (e.g. Artemieva et al., 2006; Majorowicz et al., 2003).

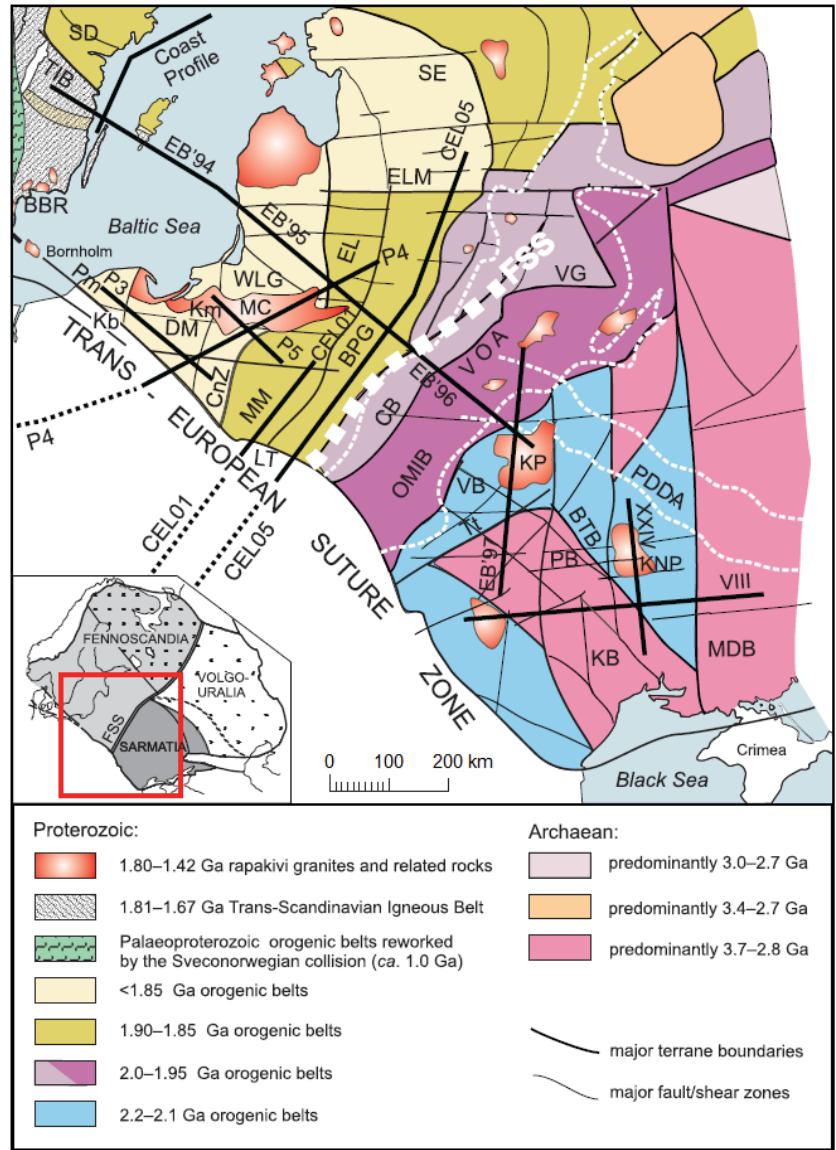

Figure 2. Simplified tectonic map (after Bogdanova et al., 2001) of the SW margin of the EEC and locations of refraction and wide-angle reflection deep seismic sounding (DSS) profiles. Solid straight lines - DSS profiles: EUROBRIDGE (EB'95, EB'96 and EB'97), POLONAISE'97 (northern part of P4, P3 and P5), VIII and XXIV profiles; dashed lines - parts of profiles in the TESZ and the Carpathians; and white dashed lines show boundaries of aulacogens. Units: BBR - Blekinge-Bornholm region; BPG - BelarusPodlasie Granulite Belt; BTB - Belaya-Tserkov Belt; CB - Central Belarus Belt; CnZ - Ciechanów Zone; DM - Dobrzyñ Massif; EL - East Lithuanian Domain; ELM - East Latvian Massif; FSS - Fennoscandia-Sarmatia Suture; KB - Kirovograd Block; $\mathrm{Kb}$ - Kaszuby Block; Km - Kêtrzyn Massif; KNP - KorsunNovomirgorod Pluton; KP - Korosten Pluton; LT - Lublin Trough; MDB - Middle Dnieper Block; MM - Mazowsze Massif; MC Mazury Complex; OMIB - Osnitsk-Mikashevichi Igneous Belt; PB - Podolian Block; Pm - Pomorze Massif; PDDA - PripyatDnieper-Donets Aulacogen; SD - Svecofennian Domain; SE South Estonian Granulites; TIB - Trans-Scandinavian Igneous Belt; $\mathrm{Tt}$ - Teterev Belt; VB - Volyn Block; VG - Vitebsk Granulite Domain; VOA - Volyn-Orsha Aulacogen; WLG - West Lithuanian Granulite Domain.

\subsection{Crustal units in Lithuania}

The NE part of the EEC is composed of several Svecofennian crustal domains (Figs. 2, 3). Grad et al. (2006) and Mo- 

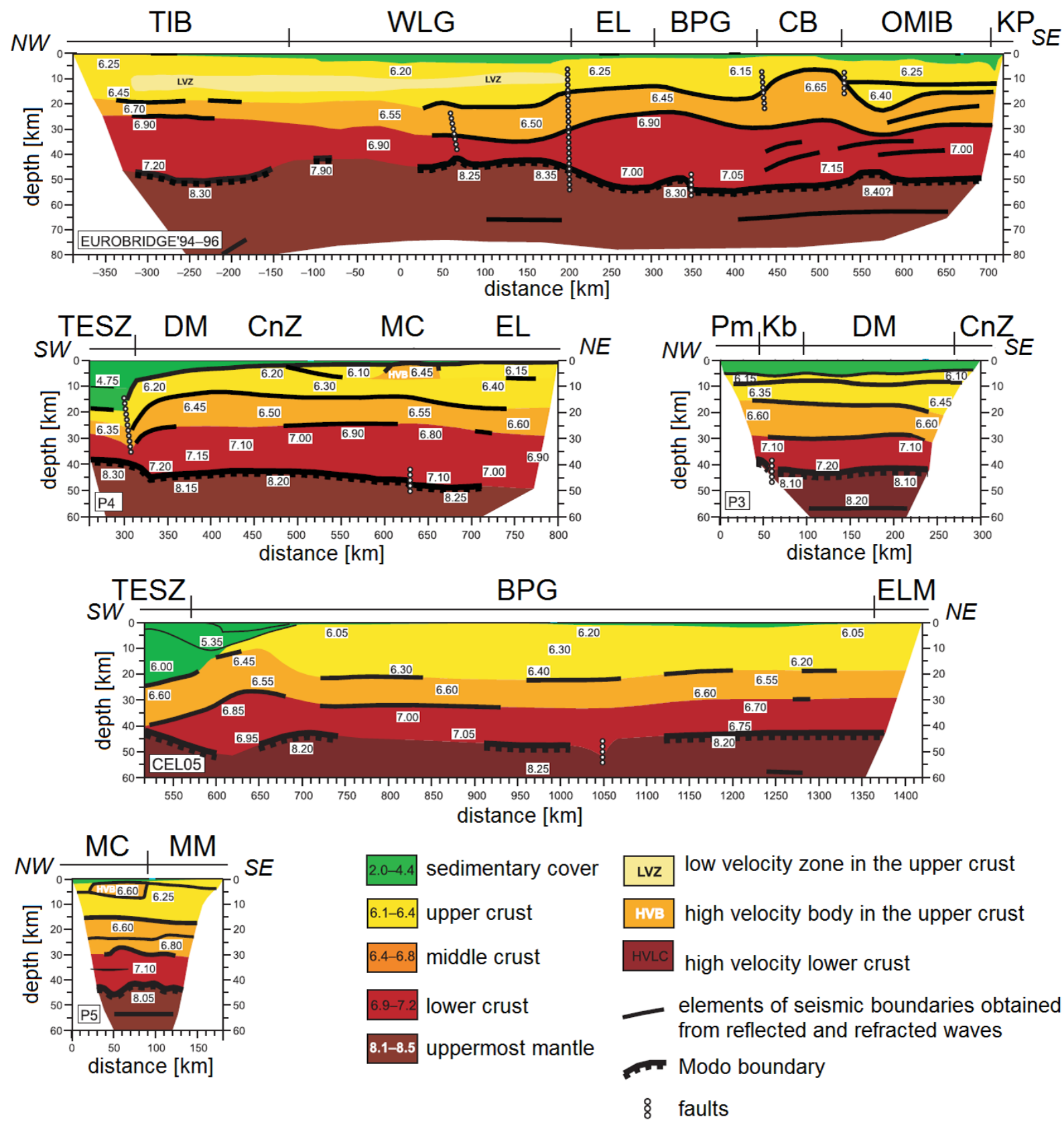

Figure 3. Models of the crust and the uppermost mantle along the EUROBRIDGE transect (EB'94 and EB'96), the POLONAISE'97 profiles P4 (northern part), P5 and P3, and CELEBRATION 2000 profile CEL05 (after Grad et al., 2006). Values of the $P$-wave velocities are given in kilometres per second. Arrows indicate positions of the shot points; the crossing points with other profiles are marked in blue. For other explanations see Fig. 2.

tuza et al. (2000) summarized the results of the DSS projects conducted in the region and distinguished different tectonic domains in the upper lithosphere along the EUROBRIGDE profile: the Västervik-Gotland block (partly occupied by the Trans-Scandinavian Igneous Belt), the West Lithuanian Granulite Domain (WLG), the East Lithuanian Domain (EL) and the Belarus-Podlasie Granulite Belt (BPG). The Moho boundary in the WLG is $42-44 \mathrm{~km}$, while in the EL and the
BPG it varies from 50 to $57 \mathrm{~km}$. The $35-40 \mathrm{~km}$ wide zone in between the WLG and the EL, with abrupt change in crustal thickness, seismic velocities and other physical parameters, is known as the Middle Lithuanian Suture Zone, which is considered as a palaeosubduction zone along which the terrain in the east subducted under the terrain in the west. Motuza (2005) also interpreted the rocks of the crystalline crust of the WLG as a back-arc complex, rocks of the Mid- 
dle Lithuania Suture Zone as a volcanic island arc complex, and the rocks of the EL as an accretionary complex. The contact between the EL and the BLG further to the NE is not so prominent (Motuza, 2005). In the WLG the seismic velocities in the uppermost mantle vary from 8.65 to $8.9 \mathrm{~km} / \mathrm{s}$ and increase along the EUROBRIDGE profile from the west to the east (Motuza et al., 2000). The crustal features of the EL show lineaments extending the NE-SW direction, which coincide with the direction of collision with Sarmatian palaeocontinent (Motuza, 2005; Bogdanova et al., 2001).

The anorogenic magmatism took place around Lithuania and the adjacent areas $1.6-1.5 \mathrm{Ga}$, resulting in a number of granitoid intrusions (Bogdanova et al., 2006). Two large granitoid bodies of rapakivi-type are present in our study area: the Riga Pluton in western Latvia, and the Mazury Complex in the Kaliningrad District of Russia and NE Poland (Rämö et al., 1996; Dörr et al., 2002).

\subsection{Crustal units in Belarus}

The junction between Fennoscandia and Sarmatia is significant in Belarus (e.g. Bogdanova et al., 1996) (Figs. 2, 3). The crustal pattern in the area shows crustal units with alternating granulite and amphibolite facies which vary in age and origin. The structural features suggest that the accretion was driven by several events of subduction and collision, and the accretionary tectonics prevailed 2.0-1.8 Ga (Bogdanova, 1999; Claesson at al., 2001).

The Volyn-Orsha Aulacogen (VOA) of Meso- to Neoproterozoic age follows the junction of Fennoscandia and Sarmatia, while the Osnitsk-Mikashevichi Igneous Belt (OMIB) represents an active continental margin along the NW edge of Sarmatia (Bogdanova et al., 1996). The 200-250 km wide OMIB consists of various grades of amphibolite facies (Aksamentova and Naydenkov, 1991) and contains large batholiths of age $2.02-1.95 \mathrm{Ga}$, which are only slightly metamorphosed and deformed, and younger rapakivi-type granites of age 1.0-1.75 Ga (Skobelev, 1987).

At the edge of Sarmatia, there are the Central Belarus Belt (CB) and the Vitebsk Granulite Domain (VG) of the Palaeoproterozoic age (about $2.0 \mathrm{Ga}$ ). The $\mathrm{VG}$ adjoins the $\mathrm{CB}$ in the east and NE. Bogdanova et al. (1996) and Stephenson et al. (1996) indicated the complex crustal structures along the Fennoscandia-Sarmatia junction with the VG and the CB slightly dipping to the SE direction beneath the edge of Sarmatia. The CB consists of bodies of amphibolite and granulite facies (Bogdanova et al., 2001) with significant tectonic faults separating the units of different composition. The study of Claesson et al. (2001) showed that the subcrustal rocks of the VG are similar to those of the southeastern CB.

\subsection{Crustal units in Poland}

The aforementioned (see Sects. 2.1 and 2.3) crustal units of prolonged shape (or "belts") from Lithuania and Belarus con- tinue in the SW direction into Polish territory (Bogdanova et al., 2006) and terminate at the TESZ (Fig. 2). The results obtained during the POLONAISE'97 (Guterch et al., 1999) and CELEBRATION 2000 DSS projects provided detailed models of the crust and the upper-mantle structure in Poland (e.g. Czuba et al., 2001; Malinowski et al., 2008). The westernmost part of the EEC adjoining the TESZ has thick continental crust of average thickness of 40-50 km (Grad et al., 2006; Guterch et al., 2004). Dadlez et al. (2005) and Grad et al. (2006) discussed in details the structure of the crust and the uppermost mantle in the SW part of the EEC, obtained by different DSS projects (Fig. 3). Some steep changes in the Moho depths and the seismic velocities along some of the profiles were reported. For example, a "step" with the increase in the Moho depth from 42 to $44 \mathrm{~km}$ (which is comparable to the resolution of the method) was found at the P5 profile between the Mazury Complex and the Mazowsze Massif (Czuba et al., 2001). Dadlez et al. (2005) summarized that not all Moho "steps" occur exactly at the places of the proposed terrain boundaries. Moreover, no clear boundaries are visible in the crust between Precambrian terrains postulated by Bogdanova et al. (1996).

\subsection{Upper mantle structure in the study area}

The cratonic lithosphere has been shown to extend to depths of about 200-250 km (Plomerova et al., 2002; Eaton et al., 2009), which is deeper than that of the younger continental regions (e.g. Shomali et al., 2006; Gregersen et al., 2010). Artemieva (2003) found thickness of the thermal lithosphere of about $250-275 \mathrm{~km}$ in the EEC for the Archean KolaKarelian province and some parts of Volgo-Uralia. However, the seismic lithosphere is systematically thicker by about $50 \mathrm{~km}$ than the thermal lithosphere (Artemieva, 2007). Sandoval et al. (2004) indicated the high-velocity anomaly extending to a depth of at least $250 \mathrm{~km}$ beneath the central part of the Fennoscandian Shield, using the method of bodywave tomography. Hjelt et al. (2006) also reported that, in the Fennoscandian Shield the seismic velocity anomalies extend to the depths of at least $250-300 \mathrm{~km}$. The study of Artemieva et al. (2006) showed the thickness of the thermal lithosphere at about $180 \mathrm{~km}$ for the EEC, while the results of geothermal modelling obtained by Majorowicz et al. (2003) indicated thermal lithosphere thickness of $200 \mathrm{~km}$ for the EEC. The study of Artemieva et al. (2006) showed thickness of the seismic lithosphere more than $250 \mathrm{~km}$, while Koulakov et al. (2009) observed high $P$-wave velocities down to $300 \mathrm{~km}$, but Geissler et al. (2010) found no clear seismic LAB beneath the SW part of the EEC.

The reflectors in the upper mantle just beneath the Moho boundary in Fennoscandia were found by Czuba et al. (2001), Yliniemi et al. (2004) and Grad et al. (2002). A major southwards dipping reflector was found beneath the EUROBRIDGE'97 profile, extending from the Moho boundary down to the depth of about $75 \mathrm{~km}$ (Thybo et al., 


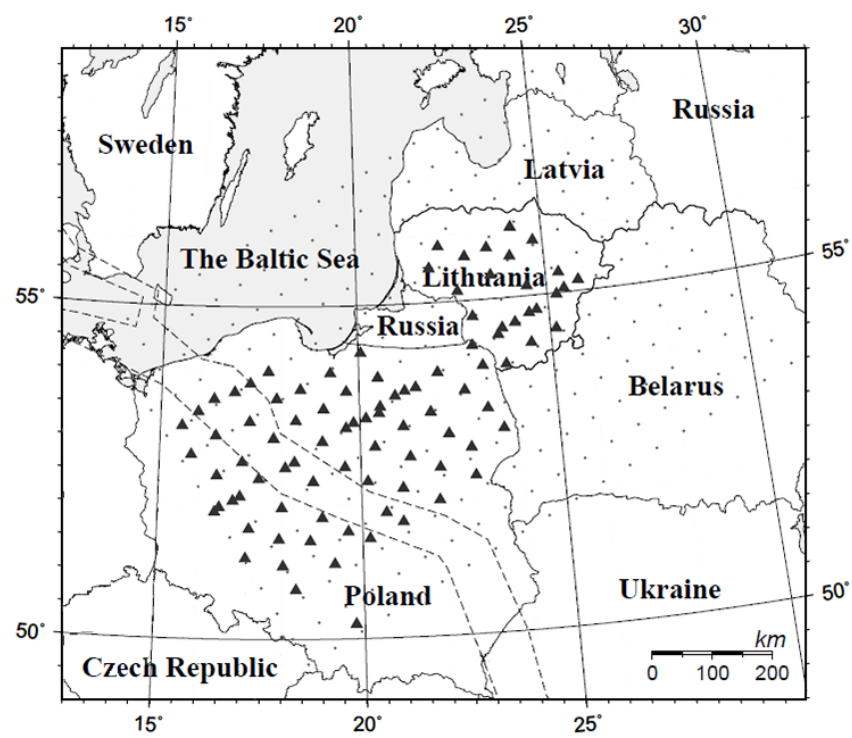

Figure 4. Map of the seismic stations (triangles) used in the study, and locations of nodes of the model grid (dots). The area in between the dashed lines indicates the TESZ.

Table 1. Data set compiled during the manual picking procedure of the $P$-wave arrivals.

\begin{tabular}{lrr}
\hline $\begin{array}{l}\text { Weighting } \\
\text { factor }\end{array}$ & $\begin{array}{r}\text { Time } \\
\text { error }\end{array}$ & $\begin{array}{r}\text { Number } \\
\text { of picks }\end{array}$ \\
\hline 1 & $<0.2 \mathrm{~s}$ & 2808 \\
2 & $0.2-0.3 \mathrm{~s}$ & 958 \\
3 & $0.3-0.4 \mathrm{~s}$ & 429 \\
\hline In total: & & 4195 \\
\hline
\end{tabular}

2003), while a steep SW-dipping mantle reflector reported was below the OMIB, and the VB correlates with a subhorizontal reflector in the EUROBRIDGE'96 profile. Similar subhorizontal lithospheric reflectors were observed beneath the TESZ (Grad et al., 2002; Guterch et al., 2004) and the Baltic Sea (Hansen and Balling, 2004). Beneath the WLGD in the upper mantle reflectors at a depth of 73-82 km were reported, which possibly originated due to delamination processes (Motuza et al., 2000; Motuza, 2005). Moreover, a locally increased heat flow ranging between 55 and $100 \mathrm{mWm}^{-2}$ was found in the WLGD (Kepezinskas et al., 1996; Rasteniene et al., 1998).

\section{Data set}

We used some of the data recorded during the PASSEQ 2006-2008 project (Wilde-Piórko et al., 2008), which took place around the TESZ from June 2006 to July 2008 (Fig. 4). Using seismological bulletins of the USGS (http: //earthquake.usgs.gov/) and the ISC (http://www.isc.ac.uk/),

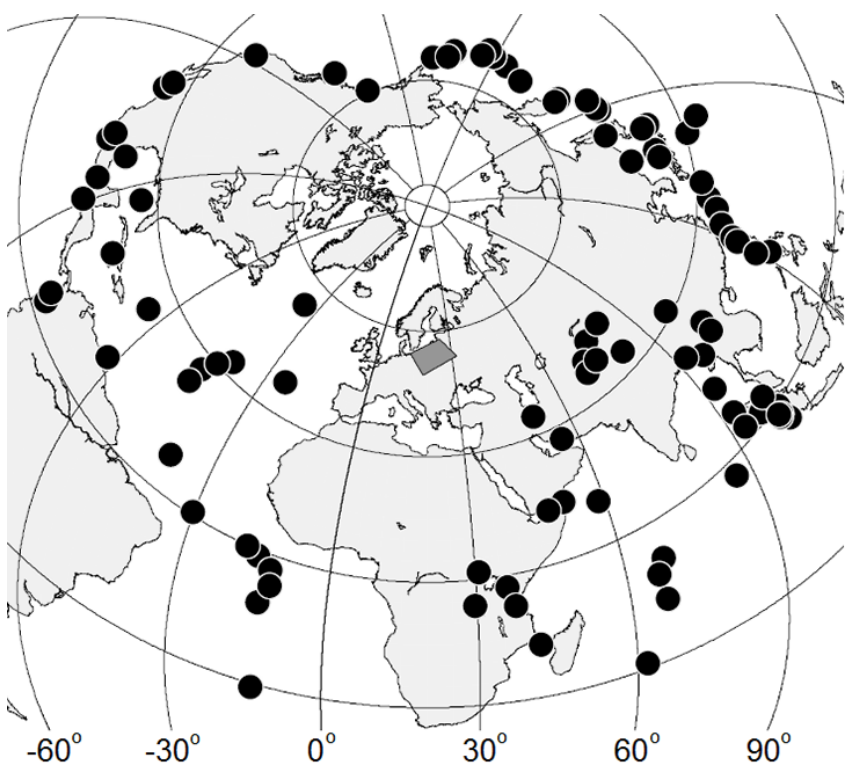

Figure 5. Map of the epicentres of $101 \mathrm{EQs}$ used in teleseismic tomography inversion. Grey rectangle indicates the study area.

we prepared a list of 101 earthquakes (EQs) with epicentral distances from 30 to 92 degrees (Artlitt, 1999; Sandoval, 2002), with respect to the central point at the LithuanianPolish border (coordinates $23^{\circ} \mathrm{E}$ and $54^{\circ} \mathrm{N}$ ) and the magnitude range from 5.5 to 7.2 (Fig. 5). The higher and lower values of the epicentral distance ensure that the first-observed arrivals are the direct $P$ waves, and that they hit the target area steeply enough from below. The relatively large magnitudes ensure better quality of the observed seismic signals. On the other hand, the magnitudes should not be too large, because it is difficult to interpret the seismic signals generated by large-scale seismic sources.

We used the Seismic Handler Motif (SHM) program package (http://www.seismic-handler.org/) to perform the analysis and manual picking of the teleseismic $P$-wave arrivals. During the data analysis, we applied the World Wide Standardized Seismographic Network short period (WWSS-SP) filter, which includes both simulation filtering and instrument response, and picked the $P$-wave arrivals on seismograms of vertical components (Fig. 6). Every $P$-wave arrival was assigned with a quality (weighting) factor depending on the time (or picking) error (Table 1). The weighting factor was taken into account during the inversion. We compiled a data set of $4195 P$-wave arrivals from the data of 94 seismic stations deployed to the east of the TESZ.

We used Seismic Handler (SH) program package and location information of the listed $101 \mathrm{EQs}$ from the ISC seismological bulletins to calculate the theoretical travel times (TTs) of the first teleseismic $P$-wave arrivals. Then we applied a subtraction procedure in order to obtain the TT residuals for 


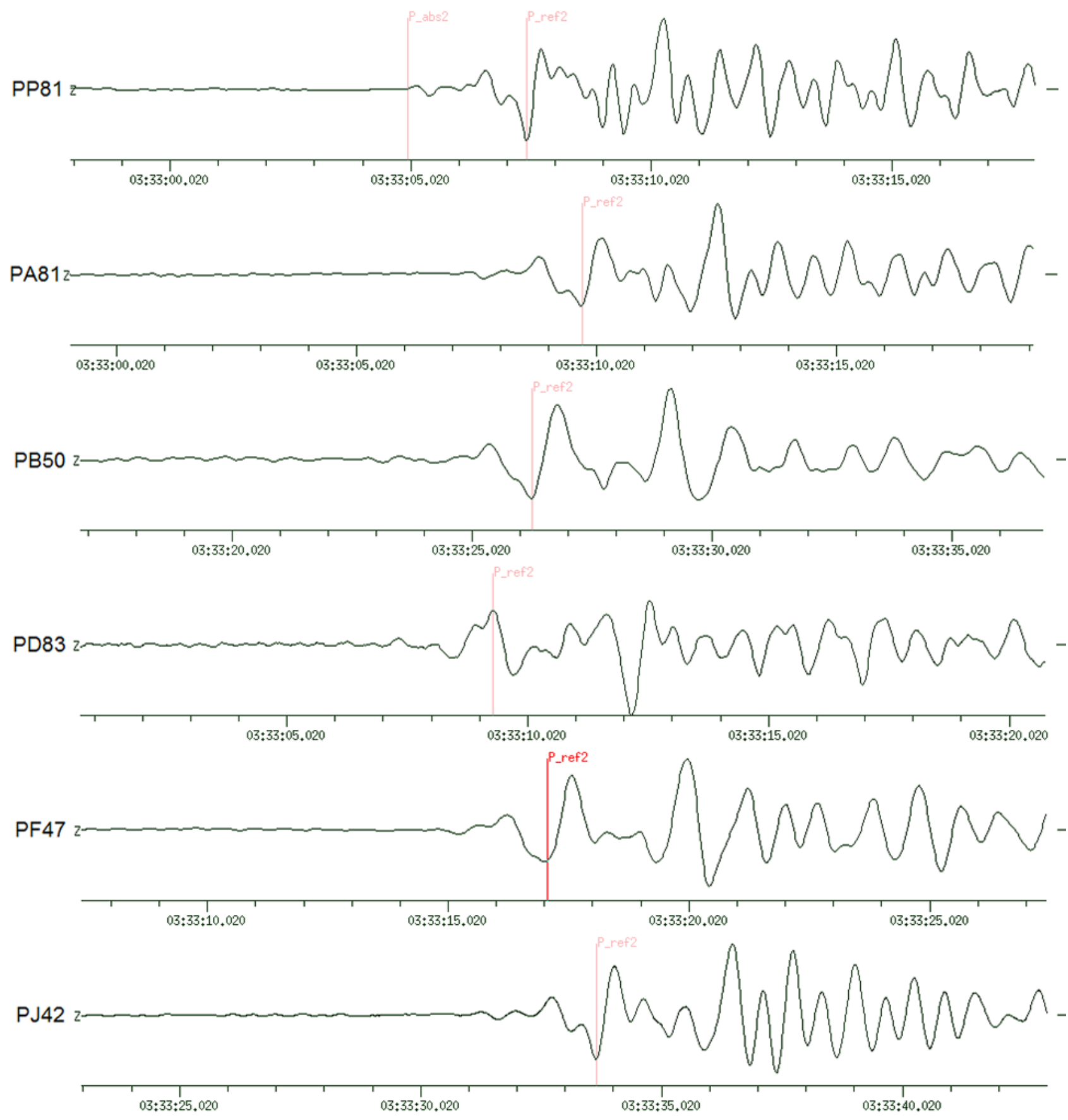

Figure 6. Example of manual picking of the $P$-wave arrivals. Filtered seismograms of an EQ on 02.08.2007 at 03:21 UTC. Out of all the seismograms we picked the best trace (the reference station) with relatively high signal-to-noise ratio (SNR) and picked the absolute $P$-wave arrival ( $\mathrm{P} \_$abs) (the onset of the $P$ wave) and the relative $P$-wave arrival $\left(\mathrm{P} \_\right.$ref) of some well-expressed minima or maxima of the seismic signal on the same trace (i.e. station PP81). Then we compared the waveform of the reference seismogram with the waveforms of other seismograms, and picked the relative $P$-wave arrivals there. For some EQs, we observed more than one type of the waveform. Thus, we grouped the events with similar waveforms and picked absolute and relative $P$-wave arrivals for each group separately. Every pick was assigned with a quality factor according to the picking error from 1 (best quality) to 3 (poor quality). The purple picks (stations PP81, PA81, PB50, PD83 and PJ42) indicate $P$-wave arrivals of quality factor 1 , while the red ones (station PF47) indicate $P$-wave arrivals of lower quality (either 2 or 3 ). In the data of some stations, we indicated inverted polarities (station PD83). 


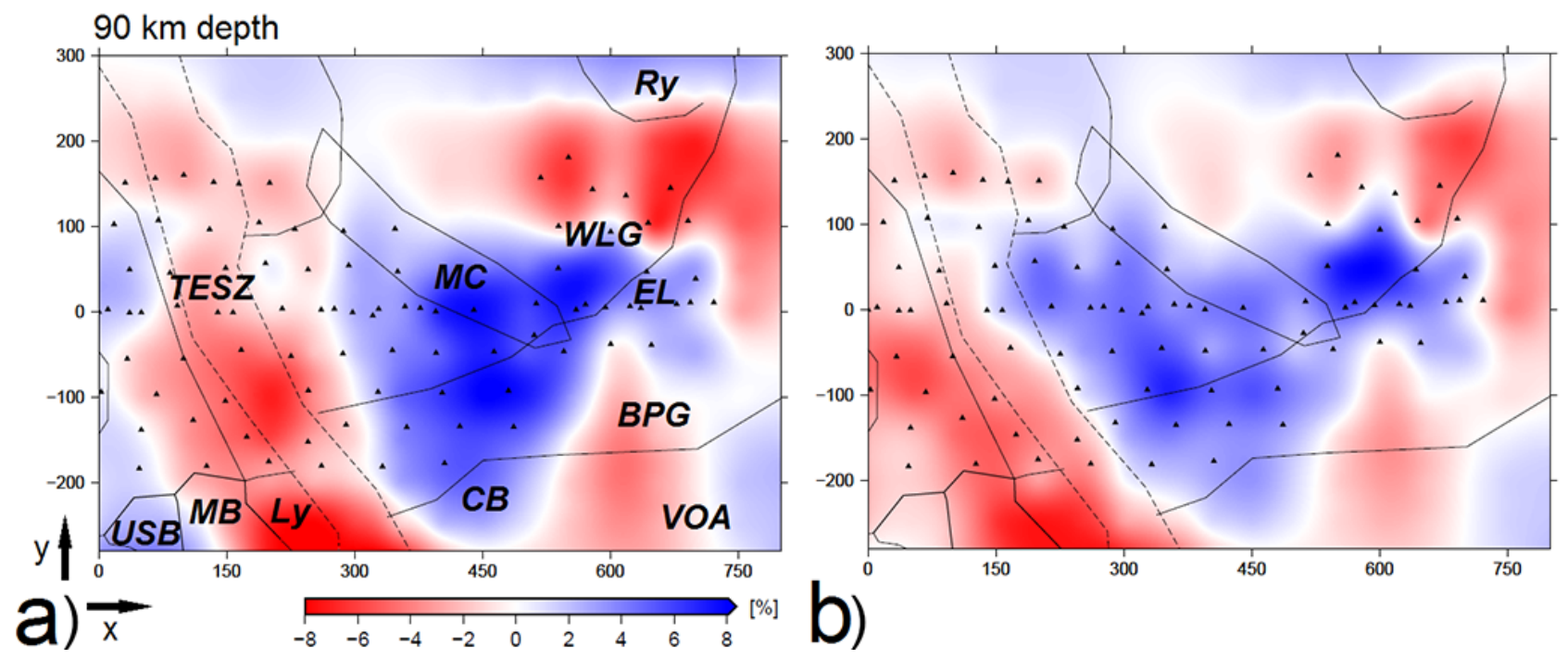

Figure 7. $P$-wave velocity variations obtained during the teleseismic tomography inversion with the real data set (a) without crustal TT corrections, and (b) with the crustal TT corrections applied. The lines indicate tectonic units: BPG - Belarus-Podlasie Granulite Belt; CB Central Belarus Belt; EL - East Lithuanian Domain Ly, Lysogory; MB - Malopolska Block; MC - Mazury Complex; Ry - Riga granitoid pluton; TESZ - Trans-European Suture Zone; USB - Upper Silesian Coal Basin; VOA - Volyn - Orsha Aulacogen; WLG - West Lithuanian Granulite Domain.

every picked arrival:

$T_{\text {picked }}-T_{\text {theoretical }}=T_{\text {residual }}$,

where $T_{\text {picked }}$ is the observed TT, $T_{\text {theoretical }}$ is the theoretical TT calculated with SH and $T_{\text {residual }}$ is the TT residual.

\section{Inversion procedure}

\subsection{Teleseismic tomography inversion}

We used TELINV code (Voss et al., 2006) to perform inversion of the compiled data set. The program utilizes a nonlinear inversion method and can either (1) calculate propagation of rays through a 3-D velocity model and output TT, raypaths and synthetic relative TT, or (2) invert teleseismic relative $P$-wave residuals for 3-D velocity structure. The ray tracing is performed by computing the 3-D minimum TT raypaths, assuming a constant slowness in each cell (Steck and Prothero, 1991). The ray coverage of the cell blocks is affected by horizontal and vertical grid spacing (Arlitt, 1999). For the full description of the inversion procedure, see Thomson and Gubbins (1982), Thuber (1983), Menke (1984), Koch (1985) and Aki et al. (1997).

\subsection{Crustal travel time corrections}

In teleseismic tomography, it is very important to use reliable crustal TT corrections in order to eliminate the effects which are created by the earth's crust, while the crust is much more heterogeneous compared to the deeper layers of the earth.
The variation of thickness of the sedimentary cover is significant in the study area ranging from several tens of metres in the Belarus-Mazurian High to almost $20 \mathrm{~km}$ in the Polish Basin, while the Moho variation is from $35 \mathrm{~km}$ beneath the TESZ to almost $60 \mathrm{~km}$ beneath NW Belarus. The teleseismic tomography inversions performed without (Fig. 7a) and with (Fig. 7b) crustal TT corrections show relatively similar distribution of the high and low velocity areas, but the seismic velocity contrast in total is up to about $4 \%$ higher in the results obtained without crustal corrections. The largest differences are observed on the eastern edge of the TESZ beneath the Polish Basin and beneath western Lithuania, where significant sedimentary covers up to 20 and $2 \mathrm{~km}$ thick, respectively, are present.

The crustal TT corrections which we use in our study have been compiled using two 3-D crustal models by Majdański (2012) for Poland (Fig. 8a left) and by M. Budraitis (unpublished) for Lithuania (Fig. 8a right). Both models have been compiled using results of available DSS projects (e.g. EUROBRIDGE, CELEBRATION, POLONAISE, BABEL, Sovietsk - Kohtla-Järve, etc.) carried out around Poland and Lithuania. We calculated the crustal TT corrections using the following equation:

$\mathrm{TT}_{\text {model }}-\mathrm{TT}_{\text {iasp }}=\mathrm{TT}_{\text {diff }}$,

where $\mathrm{TT}_{\text {model }}$ is $\mathrm{TT}$ through the crustal velocity models by Majdański (2012) or by M. Budraitis (unpublished), $\mathrm{TT}_{\text {iasp }}$ is TT through the IASP91 velocity model and TT $_{\text {diff }}$ is TT difference. Although the crustal TT corrections for individual seismic stations do not take into account the bending of the seismic rays in the crust, the result is reliable as the rays hit 

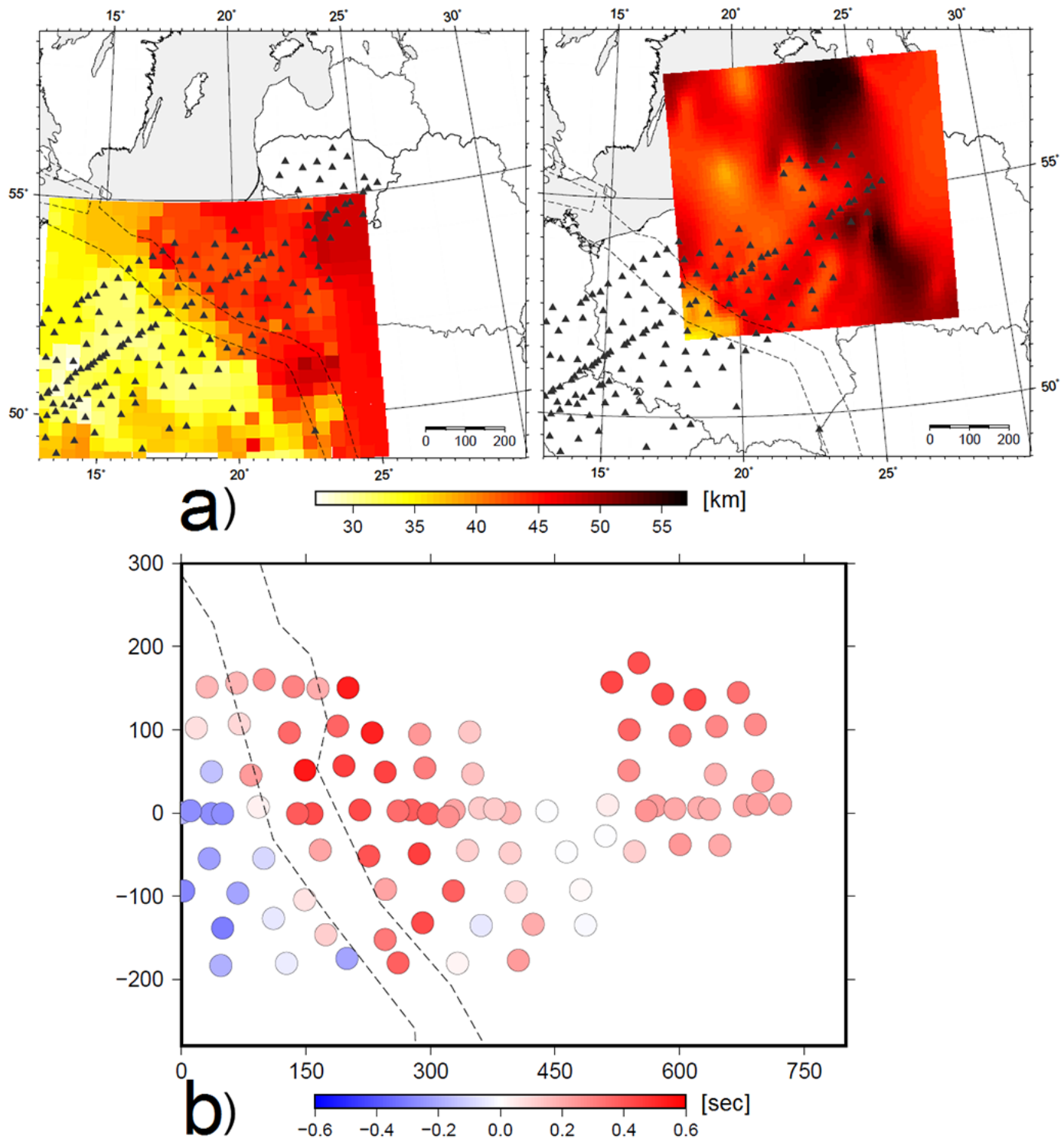

Figure 8. (a) Moho maps compiled by Majdański (2012) (left) and M. Budraitis (unpublished) (right) used to estimate the crustal TT corrections. The Moho depths in the depicted area vary from 27 to $57 \mathrm{~km}$. (b) Estimated crustal TT corrections for individual seismic stations. Values are expressed in seconds relative to the IASP91 velocity model.

the surface almost vertically and the crust is thin compared to the entire velocity structure.

\subsection{Model parameterization}

In the teleseismic tomography inversion as an input model, we used the 1-D IASP91 velocity model (Kennett and Engdahl, 1991) and transformed it into the 3-D velocity model with 16 layers of different thicknesses down to $700 \mathrm{~km}$. As the resolution of the inversion is governed by spacing between seismic stations, frequency content of the seismic signals and seismic ray geometry, we used spacing of $50 \mathrm{~km}$ between the nodes of the model grid in horizontal directions (Fig. 4). We performed a number of inversions with different values of smoothing and damping in order to assess the optimal parameters of the inversion. After careful analysis, we found that the same value as spacing between the grid nodes in horizontal directions (i.e. 50) is applicable for the diagonal elements of the smoothing matrix, while the optimal damping value 80 was determined investigating the trade-off curve between the data variance and model variance (Fig. 9).

The inversions with both the synthetic and the real data sets were performed using the defined optimal parameters of smoothing and damping for 10 layers between 60 and $350 \mathrm{~km}$ depths. 


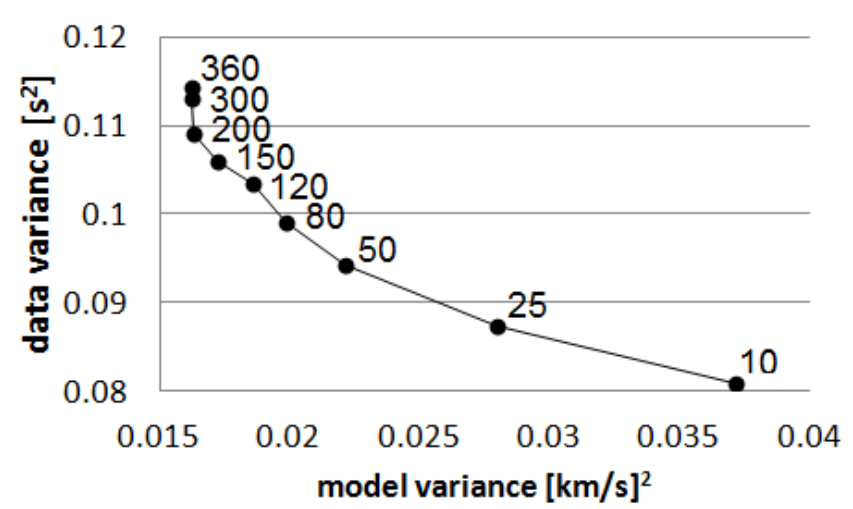

Figure 9. Data variance versus model variance obtained during inversions with damping values from 10 to 360 . The optimal damping value was set at 80 .

\section{Resolution}

The resolution assessment includes calculation of spatial resolution and standard deviations of the model parameters and helps to evaluate the precision of inversion results. In our study, we used the hit matrix method to assess the resolution, and the synthetic checkerboard test with the real station configuration in order to indicate the parts of the study area which could be reasonably resolved. The hit matrix is based on a calculation of the number of rays which transverse a particular cell (Fig. 10). The compiled synthetic checkerboard velocity model contains $200 \mathrm{~km}$ wide blocks in the horizontal directions and four layers thick with $\pm 4 \%$ velocity difference compared to the IASP91 velocity model (Fig. 11a). The inversion results show that the synthetic velocity structure is fairly well resolved in horizontal directions in the areas with good station coverage, while the vertical smearing is quite significant (Fig. 11b). The W-E smearing dipping to the east is most likely due to the seismic rays coming mainly from the NE-E-SE, because we use more EQs from the region to the east (i.e. Japan, Kamchatka, Sumatra and Aleutian regions) due to higher seismic activity compared to the region to the west of the study area.

\section{Synthetic "geological" model}

We compiled a synthetic "geological" 3-D velocity model using the velocity model by Wilde-Piórko et al. (2010) as a base, but we modified both thicknesses of different layers (because of different model grid) and some values of the seismic velocities regarding some other studies (e.g. Griffin et al., 2003). In our synthetic model (Fig. 12a), we introduced the seismic $P$-wave velocities $2-6 \%$ higher compared to the IASP91 velocity model at different depths beneath the craton. In the TESZ area, we introduced the shape of a ramp-type of the lithosphere-asthenosphere boundary (LAB) dipping to the NE with seismic velocity values close

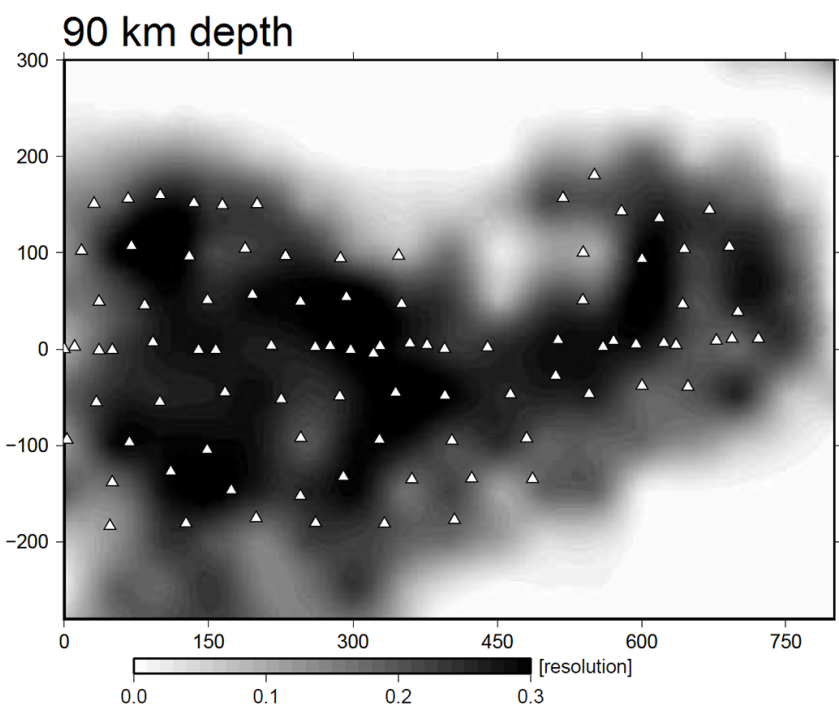

Figure 10. Resolution at depth of $90 \mathrm{~km}$ for the field data set. Low and high values show, respectively, poorly and well-resolved areas. White triangles mark the seismic stations.

to those of the cratonic part but up to $2 \%$ smaller in the upper layers down to about $180 \mathrm{~km}$. At the depths between 270 and $350 \mathrm{~km}$, we introduced velocities 2 to $4 \%$ lower compared to the IASP91 velocity model, and the higher velocity area (about $3 \%$ higher $P$-wave velocities compared to the IASP91 velocity model) in the NE part, which implies that we expect the deeper cratonic roots in this part of the study area.

With the synthetic data set, we performed inversions without (Fig. 12b) and with (Fig. 12c) the crustal TT corrections, as used with the field data. The crustal corrections were applied in order to obtain similar raypaths in the upper layers, and to estimate the effects of the crustal corrections to the signal amplitudes and the depth to which this effect is significant. The inversion results with the crustal TT corrections (Fig. 12c) show in total about $2.5 \%$ higher signal amplitudes (both positive and negative) compared to the results obtained without crustal corrections (Fig. 12b). This high value of signal amplitudes is caused because the synthetic data set was compiled using theoretical TT only, while the crustal corrections used with the field data reduces the signal amplitudes (Fig. 7). Moreover, we indicate that the effect due to the crustal TT corrections is significant (up to $0.5 \%$ ) down to about $120 \mathrm{~km}$, while, going deeper, the effect is negligible (Fig. 12b, c). Both results obtained using the synthetic data set with and without crustal TT corrections (Fig. 12b, c) show reasonably resolved ramp-type shape of the LAB and the deep cratonic roots going down to $350 \mathrm{~km}$ in the NE part of the study area. 


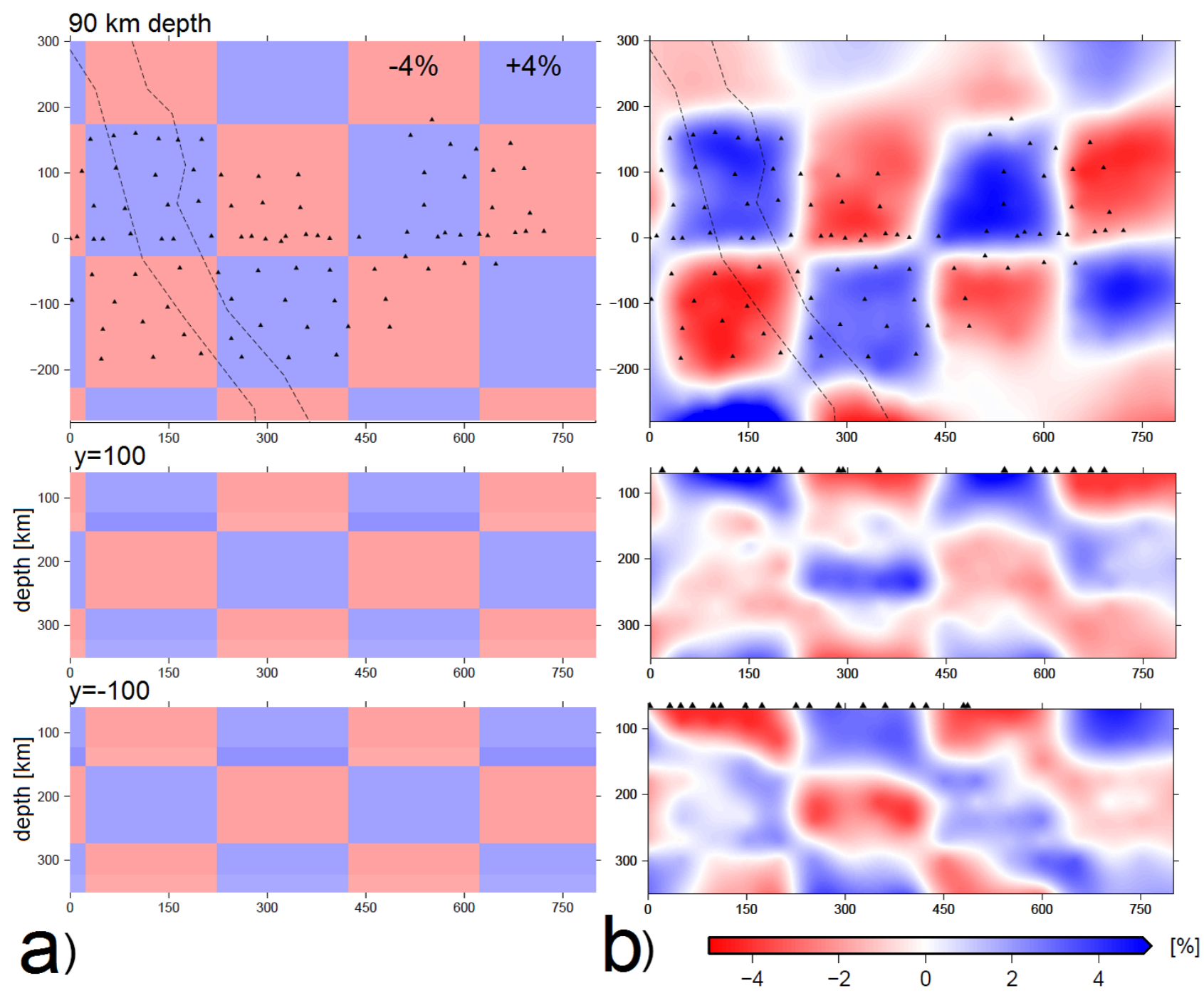

Figure 11. Results of the synthetic checkerboard test. We added small random perturbations to the compiled synthetic data set. Horizontal slice at a depth of $90 \mathrm{~km}$ and two vertical slices parallel to the main PASSEQ transect of the target area. (a) Initial velocity model with synthetic blocks of $200 \mathrm{~km}$ wide in the horizontal directions and $\pm 4 \% P$-wave velocity difference compared to the IASP91 velocity model. (b) Inversion results with the synthetic data set. Dashed lines indicate the TESZ. Triangles indicate the seismic stations, and on the vertical slices they indicate seismic stations $\pm 50 \mathrm{~km}$ around the depicted transects.

\section{Results and discussion}

In teleseismic tomography, many factors - which are related to either the model parameterization or the field data set influence the observed signal amplitudes: (1) in teleseismic tomography only a part of the ray path through the velocity model is inverted. However, the rays experience distortions along their full paths from source to receiver (i.e. outside the velocity model) which are mapped in the final results of the inversion, and add up to positive or negative signals; (2) the TELINV code used in this study implements the "flat-earth" transformation which has an effect on the apparent velocities when dealing with large study areas. Our study area is $800 \mathrm{~km}$ in the longest direction and the model is set to the depth of $700 \mathrm{~km}$. Thus, the model at the bottom is horizontally stretched by about $11 \%$. Regarding the incidence angles of our data set, the effect on velocity perturbations due to the flat-earth transformation is about $1.5 \%$ of the observed velocity contrast. However, we did not apply any corrections for the spherical model; (3) the damping value has an influence on the velocity contrast - the larger the value, the smaller the velocity contrast. On the other hand, too high a damping value would result in reduction of lateral variations. The optimal damping value (which is 80 ) used in the inversion was set after careful analysis (Fig. 9); (4) the precise crustal TT corrections are essential in teleseismic tomography in order to eliminate (or reduce) the crustal effects. We applied the crustal TT corrections assuming vertical ray 

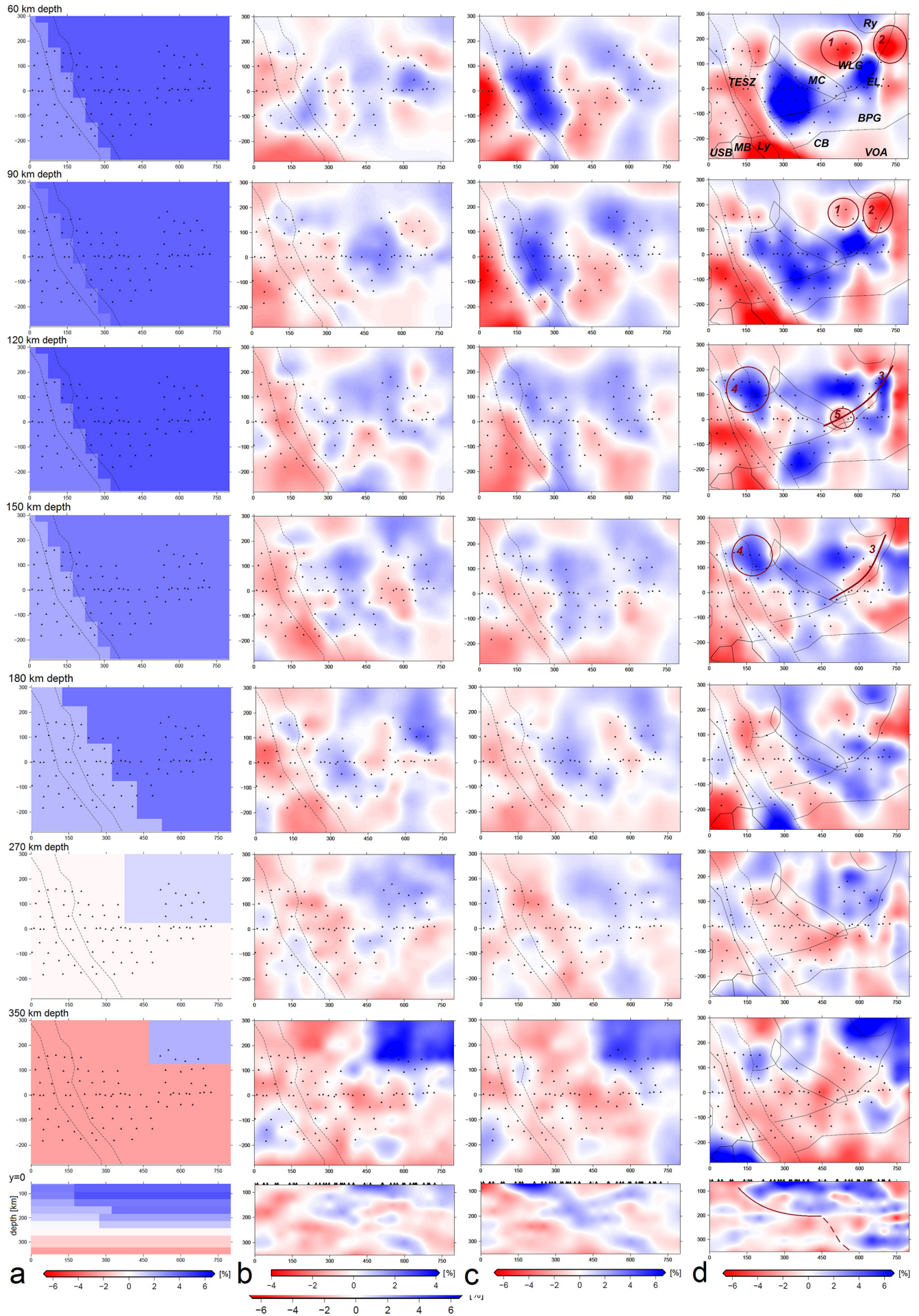

Figure 12. The initial synthetic "geological" velocity model (a), the inversion results with the synthetic data set with (c) and without (b) the crustal TT corrections, and the inversion results with the real data set with applied crustal TT corrections (d). The $P$-wave velocity perturbations on the horizontal slices at different depths and the vertical slice along the main PASSEQ transect. The bluish and reddish areas show, respectively, the higher and the lower $P$-wave velocities compared to the IASP91 velocity model. The thin dashed lines on the horizontal slices indicate the TESZ. Triangles indicate the seismic stations, and on the vertical slices they indicate seismic stations $\pm 50 \mathrm{~km}$ around the main PASSEQ transect. The solid thin lines on the horizontal slices (right side) indicate boundaries of different tectonic units (for detailed explanation see Fig. 7). Interpreted velocity anomalies on horizontal slices: 1 - upper-mantle dome; 2 - effect from the Riga batholith; 3 - palaeosubduction boundary between the WLG and the EL; 4 - higher velocity anomaly beneath the northern part of the TESZ; and 5 - effect from the Mazury Complex. Solid and dashed lines on vertical slice mark the interpreted LAB. 

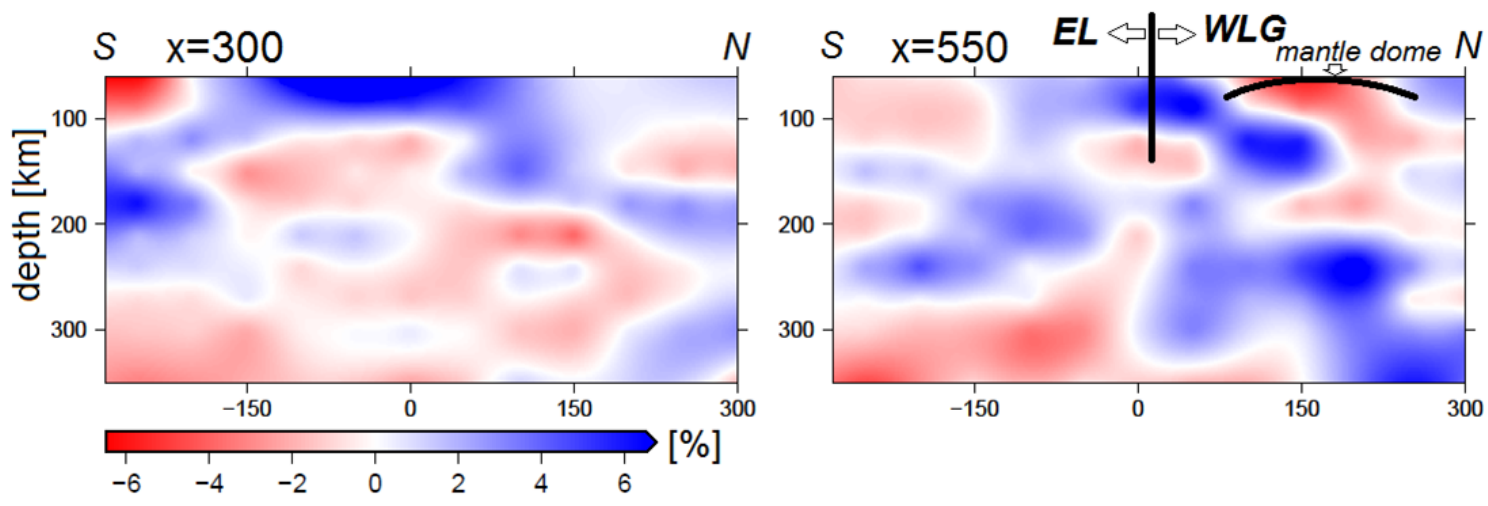

Figure 13. Vertical slices perpendicular to the main PASSEQ transect close to the eastern edge of the TESZ (left), and about $350 \mathrm{~km}$ to the NE from the TESZ (right). The thick lines indicate possibly resolved boundary between the EL and the WLG, and the mantle dome beneath the WLG.

propagation in the crust. However, its effect to signal amplitudes is negligible. The larger effect (up to $1 \%$ ) can be caused by the used crustal models because they have their own limit of precision; (5) the increase in signal contrast in the results due to temperature variations could be up to about $1 \%$ because, in the study, the heat-flow variations are significant; (6) some anisotropy studies of share-wave splitting (e.g. Wüstefeld et al., 2010; Vecsey et al., 2013; Sroda et al., 2014) show relatively small anisotropy for the EEC compared to the territories to the west of the TESZ. Thus, its effects to the observed velocity contrast should be quite small (up to about $0.5 \%$ ). Taking into account all the above-listed causes, we should consider the velocity contrast not up to $\pm 6 \%$, which we observe in our results (Figs. 12d, 13), but close to $\pm 3 \%$.

\subsection{Lithosphere structure}

In our study area, we resolved structure of the upper mantle from $60 \mathrm{~km}$ down to $350 \mathrm{~km}$ (Figs. 12d, 13). Beneath the EEC (Fig. 12c) we obtain up to $3 \%$ higher seismic velocities compared to the IASP91 velocity model. The higher velocities in the upper mantle can be traced going down to the depth of about $180 \mathrm{~km}$ beneath NE Poland which coincides with the results of Wilde-Piórko et al. (2010) and Majorowicz et al. (2003). Going further to the NE the lithosphere thickness increases and beneath Lithuania it is at least $300 \mathrm{~km}$ or more, which coincides well with observations by Koulakov et al. (2009). Thick lithosphere was previously reported for other cratonic areas, i.e. the Fennoscandian Shield (Sandoval et al., 2004), but no evidence of the seismic LAB was found anywhere within the depth of $300 \mathrm{~km}$ beneath the Fennoscandian Shield (Bruneton et al., 2004). The shear-wave studies of Legendre et al. (2012) showed no deep cratonic roots below about $330 \mathrm{~km}$ in the EEC. There is a good correlation between our results obtained with the real data set and the synthetic data set (Fig. 12), which implies that the lithosphere thickness may increase going from the TESZ towards the NE and could be larger than $300 \mathrm{~km}$ in the EEC. Moreover, the results with the synthetic data set show that the $P$-wave velocities beneath the craton down to $180 \mathrm{~km}$ could be about $3 \%$ higher compared to the IASP91 velocity model.

In the EEC beneath western Lithuania (i.e. the WLG) down to $90 \mathrm{~km}$, we observe the lower seismic velocities (Fig. 13) which could be related to an upper-mantle dome. Motuza et al. (2000) proposed that the mantle dome could be related with delamination processes because, beneath the WLG, the heat flow, which is significantly higher compared to the adjacent areas, was observed (Kepezinskas et al., 1996; Rasteniene et al., 1998) and the high-density reflectors in the upper mantle have been found (Giese, 1998; Motuza et al. 2000). These high-density bodies can potentially represent delaminated slices of the crust which sank into the mantle (e.g. Defant and Kepezhinskas, 2002). In our results (Figs. 12c, 13), we do not find any well-defined high velocity reflector in the upper mantle. On the other hand, below the discussed low velocity area (i.e. the proposed upper-mantle dome), we observe area of velocities which are significantly higher than those of the surroundings. As the delamination processes occur locally, the lower and the higher velocity areas observed in our results beneath the WLG could possibly be related to the local upper-mantle dome and the delaminated high-density rocks.

Beneath the TESZ, we find about 2 to $3 \%$ smaller seismic velocities compared to the IASP91 velocity model, except for the northern TESZ (northern Poland), where we observe the values of seismic velocities close to those of the craton down to about $150 \mathrm{~km}$. In their work, Knapmeyer-Endrun et al. (2013) observe an increase in TT of Ps conversions across the mantle transition zone which they think could be caused either by a temperature reduction or an increase in water content.

In the northern part of the TESZ, we find the seismic LAB at a depth of about $180 \mathrm{~km}$ (Fig. 12d). We also indicate the seismic LAB of a ramp-type dipping towards the NE, which coincides with the inversion results obtained with the syn- 
thetic data set (Fig. 12). Hansen and Balling (2004) also reported on a number of mantle reflectors beneath the Baltic Sea along the TESZ dipping towards the N-NE.

The velocity model by Wilde-Piórko et al. (2010) proposed the higher $P$-wave velocity values compared to the IASP91 velocity model for the TESZ and the cratonic area for depths more than $250 \mathrm{~km}$. Our results with the real and the synthetic data sets (Fig. 12) indicate that the seismic velocities at these depths are 1-2\% smaller or similar compared to the IASP91 velocity model.

\subsection{Traces of the crustal units}

The crustal units are not well resolved in our results. There are no clear indications of the structures (Fig. 2) in the upper mantle (the uppermost inverted layers of the velocity model) which could be related with the crustal units in the study area (Figs. 12c, 13). However, in the uppermost inverted layers we find correlation between the Moho depth and velocity variations: the positive signal amplitudes are usually observed in the areas with thicker continental crust beneath Poland and Lithuania, while the negative ones are in the areas with thinner crust beneath the TESZ. This could be related either to the imperfect crustal TT corrections used or to different geological conditions. We may infer only one possibly resolved boundary between the EL and the WLG beneath Lithuania, which could be related to the local lower velocity areas at the depths from $120 \mathrm{~km}$ to at least $150 \mathrm{~km}$. This area was interpreted by Motuza (2005) and Motuza and Staškus (2009) as a palaeosubduction zone. The other possible explanation for the lower velocity area beneath the southernmost region of Lithuania - NE Poland at a depth of 100-120 km - is an effect due to an anorogenic granitoid massif, the Mazury Complex (Fig. 7), which is $40 \mathrm{~km}$ wide and $6.5 \mathrm{~km}$ thick, extending $200 \mathrm{~km}$ from the Baltic Sea through the Kaliningrad District of Russia into NE Poland. A number of studies (e.g. Bruneton et al., 2004; Beller et al., 2013) showed that the upper mantle beneath anorogenic granitoid massifs inside cratonic crust is different from that of the surrounding cratonic mantle. There is another anorogenic granitoid massif, the Riga Pluton (Fig. 7), in western Latvia which, in our results, could be related to the lower velocity area down to about $150 \mathrm{~km}$ in the NE region of our study area. As the granitoid massif lies on the edge of the study area where resolution is quite poor, we cannot assert its effects on our results. Both the Mazury Complex and the Riga Pluton are of rapakivi type and have formed 1.6-1.5 Ga (Rämö et al., 1996; Dörr et al., 2002).

\section{Conclusions}

- Beneath the EEC, we obtain up to $3 \%$ higher seismic velocities compared to the IASP91 velocity model. The lithosphere thickness increases towards the NE from about $180 \mathrm{~km}$ beneath NE Poland to at least $300 \mathrm{~km}$ or more beneath Lithuania.

- Beneath the TESZ, we find the seismic velocities 2-3\% smaller compared to the IASP91 velocity model, and only in the northern TESZ do we observe higher seismic velocities down to about $150 \mathrm{~km}$, which show that the northern part of the TESZ is more craton-like.

- The seismic LAB beneath the northern part of the TESZ is at a depth of about $180 \mathrm{~km}$, and it is most likely of the shape of a ramp. We did not find the seismic LAB beneath the EEC.

- The seismic velocities in our study area at the depths more than $250 \mathrm{~km}$ could be $1-2 \%$ smaller or similar compared to the IASP91 velocity model.

- The observed local lower and higher velocities beneath western Lithuania might be related to an upper-mantle dome.

- In our results, we did not find a strong correlation between the separate crustal units and the upper mantle. However, we observe that the positive signal amplitudes coincide with the areas with thicker continental crust, while the negative ones coincide with areas with thinner crust. We also recognize the trace of the palaeosubduction boundary between the EL and the WLG beneath Lithuania.

- In our results, we possibly identified the Riga and the Mazury anorogenic granitoid plutons.

Acknowledgements. Our study is a part of the PASSEQ 2006-2008 project (Wilde-Piórko et al., 2008). The study was partly funded by NordQuake project. The cut one-event files in mSEED format used for data review and picking of teleseismic $P$-wave arrivals were created at the Institute of Geosciences Polish Academy of Sciences, Warsaw, Poland. The figures were produced using GMT program (Wessel and Smith, 1991). The data review, picking of the $P$-wave arrivals and calculations of the theoretical $P$ wave arrivals were performed using SHM program package (http: //www.seismic-handler.org/). Special thanks to Gediminas Motuza for guidance and constructive advice. Special thanks to Hanna Silvennoinen for help with TELINV code and other useful discussions. We also thank U. Achauer, Y. Yang and an anonymous referee who helped to improve the quality of this paper.

7 PASSEQ Working Group: Monika WildePiorko ${ }^{(\mathrm{I})}$, Wolfram H. Geissler $^{(I I)}$, Jaroslava Plomerova(III), Marek Grad ${ }^{(I)}$, Vladislav Babuška (III), Ewald Bruckl ${ }^{(I V)}$, Jolanta Cyziene ${ }^{(\mathrm{V})}$, Wojciech Czuba $^{(\mathrm{VI})}$, Richard England ${ }^{(\mathrm{VII})}$, Edward Gaczyński(VI), Renata

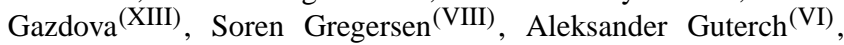
Winfried Hanka $^{(\mathrm{VII})}$, Endre Hegedús $(\mathrm{X})$, Barbara Heuer ${ }^{(\mathrm{IX})}$, Petr Jedlička $^{(\mathrm{III})}$, Jurga Lazauskiene ${ }^{(\mathrm{V}, \mathrm{XVII})}$, G. Randy $\operatorname{Keller}^{(\mathrm{XI})}$, Rainer Kind ${ }^{(\mathrm{IX})}$, Klaus Klinge ${ }^{(\mathrm{XII})}$, Petr Kolinsky ${ }^{(\mathrm{XIII})}$, Kari Komminaho $^{(X I V)}$, Elena Kozlovskaya ${ }^{(X V)}$, Frank Kruger ${ }^{(X V I)}$, 


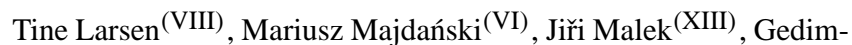
inas Motuza ${ }^{(X V I I)}$, Oldřich Novotny ${ }^{(X I I I)}$, Robert Pietrasiak ${ }^{(V I)}$, Thomas Plenefisch ${ }^{(X I I)}$, Bohuslav Růžek ${ }^{(I I I)}$, Saulius Sliaupa ${ }^{(V)}$,' Piotr Środa ${ }^{(\mathrm{VI})}$, Marzena Świeczak ${ }^{(\mathrm{VI})}$, Timo Tiira ${ }^{(\mathrm{XIV})}$, Peter Voss ${ }^{(V I I I)}$, PawełWiejacz ${ }^{(\mathrm{VI})}$. (I) University of Warsaw, Warsaw, Poland; (II) Alfred Wegener Institute for Polar and Marine Research, Bremerhaven, Germany; (III) Institute of Geophysics Czech Academy of Sciences, Prague, Czech Republic; (IV) Vienna University of Technology, Vienna, Austria; (V) Geological Survey of Lithuania, Vilnius, Lithuania; (VI) Institute of Geophysics Polish Academy of Sciences, Warsaw, Poland; (VII) University of Leicester, Leicester, Great Britain; (VIII) Geological Survey of Denmark and Greenland, Copenhagen, Denmark; (IX) GeoForschungsZentrum Potsdam, Potsdam, Germany; (X) Eötvös Loránd Geophysical Institute, Budapest, Hungary; (XI) University of Oklahoma, Norman, USA; (XII) Seismological Central Observatory, Erlangen, Germany; (XIII) Institute of Rock Structure and Mechanics Czech Academy of Sciences, Prague, Czech Republic; (XIV) University of Helsinki, Helsinki, Finland; (XV) University of Oulu, Oulu, Finland; (XVI) University of Potsdam, Potsdam, Germany; ${ }^{(X V I I)}$ University of Vilnius, Vilnius, Lithuania.

Special Issue: "The Lithosphere-Asthenosphere Boundary (LAB) Dilemma"

Edited by: U. Achauer, J. Plomerova, and R. Kind

\section{References}

Aki, K., A. Christoffersson, and Husebye, E. S.: Determination of the three-dimensional seismic structure of the lithosphere, J. Geophys. Res., 82, 277-296, 1977.

Aksamentova, N. V. and Naydenkov, I. V.: Explanatory note of the geological map of the crystalline basement of Belorussia and the Adjoining Areas. Academy of Sciences of the Belorussian SSR, Minsk, 1991.

Arlitt, R.: Teleseismic body wave tomography across the TransEuropean Suture Zone between Sweden and Denmark. PhD theses, ETH, Swiss Federal Institute of Technology Zürich, Swiss, 1999.

Artemieva, I. M.: Lithospheric structure, composition, and thermal regime of the East European craton: implications for the subsidence of the Russian Platform. Earth Planet. Sci. Lett. 213, 429444, 2003.

Artemieva, I. M., Thybo, H., and Kaban, M. K.: Deep Europe today: Geophysical synthesis of the upper mantle structure and lithospheric processes over 3.5 Ga. In: Gee, D., and Stephenson, R. (eds.), European Lithosphere Dynamics, Geol. Soc. London, Special Publication, 32, 11-41, 2006.

Artemieva, I. M.: Dynamic topography of the East European craton: Shedding light upon lithospheric structure, composition and mantle dynamics, Glob. Planet. Change, 58, 411-434, 2007.

Beller, S., Kozlovskaya, E., Achauer, U., and Tiberi, Ch.: Joint inversion of teleseismic and gravity data beneath the Fennoscandian Shield. EGU General Assembly 2013, Geophys. Res. Abstr., 15, EGU 2013-4771-2, 2013.

Bogdanova, S. V.: The Palaeoproterozoic terrane pattern in the western part of the East European Craton, Seventh EUROBRIDGE Workshop, Polish Geological Institute, Suwalki, Poland, 11-13, 1999.
Bogdanova, S. V., Pashkevich, I. K., Gorbachev, R., and Orlyuk, M. I.: Riphean rifting and major Palaeoproterozoic boundaries in the East European Craton: geology and geophysics, Tectonophysics, 268, 1-21, 1996.

Bogdanova, S. V., Page, L. M., and Taran, L. N.: Proterozoic tectonothermal history in the western part of the East European Craton: ${ }^{40} \mathrm{Ar} /{ }^{39} \mathrm{Ar}$ geochronological consraints, Tectonophysics, 339, 39-66, 2001.

Bogdanova, S. V., Gorbatschev, R., Grad, M., Janik, T., Guterch, A., Kozlovskaya, E., Motuza, G., Skridlaite, G., Starostenko, V., Taran, L., the EUROBRIDGE and POLONAISE Working Groups: EUROBRIDGE: new insight into the geodynamic evolution of the East European Craton, in: European Lithospheric Dynamics, edited by: Gee, D. G. and Stephenson, R. A., Memoirs Number 32, Geological Society, London, 599-625, 2006.

Bruneton, M., Pedersen, H. A., Farra, V., Arndt, N. T., Vacher, P., Achauer, U., Alinaghi, A., Ansorge, J., Bock, G., Friederich,W., Grad, M., Guterch, A., Heikkinen, P., Hjelt, S.-E., Hyvönen, T. L., Ikonen, J.-P., Kissling, E., Komminaho, K., Korja, A., Kozlovskaya, E., Nevsky, M. V., Paulssen, H., Pavlenkova, N. I., Plomerová, J., Raita, T., Riznichenko, O. Y., Roberts, R. G., Sandoval, S., Sanina, I. A., Sharov, N. V., Shomali, Z. H., Tiikkainen, J., Wielandt, E., Wilegalla, K., Yliniemi, J., and Yurov, Y. G.: Complex lithospheric structure under the central Baltic Shield from surface wave tomography, J. Geophys. Res., 109, B10303, doi:10.1029/2003JB002947, 2004.

Claesson, S., Bibikova, E. V., Bogdanova, S. V., and Gorbatschev, R.: Isotopic evidence of Plaeoproterozoic accretion in the basement of the East European Craton, Tectonophysics, 339, 1-18, 2001.

Czuba, W., Grad, M., Luosto, U., Motuza, G., Nasedkin, V., and POLONAISE P5 Working Group: Crustal structure of the East European craton along the POLONAISE'97 P5 profile, Acta Geoph. Pol., 49, 145-168, 2001.

Dadlez, R., Grad, M., and Guterch, A.: Crustal structure below the Polish Basin: Is it composed of proximal terranes derived from Baltica?, Tectonophysics, 411, 111-128, 2005.

Defant, M. J. and Kepezhinskas, P.: Adakites: some variations on a theme. Acta Petrol, Sinica, 18, 129-142, 2002.

Dörr, W., Belka, Z., Marheine, D., Schastok, J., Valverde Vaquero, P., and Wiszniewska, J.: U-Pb and Ar-Ar geochronology of anorogenic granite magmatism of the Mazury complex NE Poland, in: Precambrian Research, edited by: Rämo, T., Special issue, 119, 101-102, 2002.

Eaton, D. W., Darbyshire, F., Evans, R. L., Grütter, H., Jones, A. G., and Yuan, X.: The elusive lithosphere-asthenosphere boundary (LAB) beneath cratons. Lithos., 109, 1-22, 2009.

EUROBRIDGE SeismicWorking Group: Seismic velocity structure across the Fennoscandia-Sarmatia suture of the East European Craton beneath the EUROBRIDGE profile through Lithuania and Belarus, Tectonophysics, 314, 193-217, 1999.

Geissler, W. H., Sodoudi, F., and Kind, R.: Thickness of the central and eastern European lithosphere as seen by $S$ receiver functions. Geophys. J. Int., 181, 604-634, 2010.

Giese, R.: Eine zweidimensionale Interpretation der Geschwindigkeitenstruktur der Erdkruste des sudwestlichen Teils der osteuropaischen Platform (Project Eurobridge): Scientific Technical Report STR98/16, Potsdam, 190 pp., 1998. 
Gorbatschev, R. and Bogdanova, S.: Frontiers in the Baltic Shield, Precambrian Res., 64, 3-21, 1993.

Grad, M., Keller, G. R., Thybo, H., Guterch, A., and POLONAISE Working Group, Lower lithospheric structure beneath the TransEuropean Suture Zone from POLONAISE'97 seismic profiles, Tectonophysics, 360, 153-168, 2002.

Grad, M., Janik, T., Guterch, A., Sroda, P., Czuba, W., EUROBRIDGE'94-97, POLONAISE'97 and CELEBRATION 2000 Seismic Working Groups: Lithospheric structure of the western part of the East European Craton investigated by deep seismic profiles, Geol. Quart., 50, 9-22, 2006.

Gregersen, S., Voss, P., Nielsen, L. V., Achauer, U., Busche, H., Rabbel, W., and Shomali, Z. H.: Uniqueness of modeling results from teleseismic $P$ wave tomography in Project TOR, Tectonophysics, 481, 99-107, 2010.

Griffin, W. L., O’Reilly, S. Y., Abe, N., Aulbach, S., Davies, R. M., Pearson N. J., Doyle, B. J., and Kivi, K.: The origin and evolution of Archean lithospheric mantle, Precambrian Res., 127, 19-41, 2003.

Guterch, A., Grad, M., Thybo, H., Keller, G. R., and the POLONAISE Working Group: POLONAISE'97 - an international seismic experiment between Precambrian and Variscan Europe in Poland, Tectonophysics, 314, 101-121, 1999.

Guterch, A., Grad, M., Keller, G. R., and POLONAISE'97, CELEBRATION 2000, ALP 2002, SUDETES 2003 Working Groups: Huge contrasts of the lithospheric structure revealed by new generation seismic experiments in Central Europe, Przegld Geologiczny, 52, 2004.

Hansen, T. M. and Balling, N.: Upper-mantle reflectors: modeling of seismic wavefield characteristics and tectonic implications, Geophys. J. Int, 157, 664-682, 2004.

Kennett, B. L. N. and Engdahl, E. R.: Traveltimes for global earthquake location and phase identification, Geophys. J. Int., 105, 429-465, 1991.

Kepezinskas, K., Rasteniene, V., and Suveizdis, P.: West Lithuanian geothermal anomaly, Vilnius, 1-68, 1996.

Knapmeyer-Endrun, B., Krüger, F., Legendre, C. P., Geissler, W. H., and PASSEQ Working Group: Tracing the influence of the TransEuropean Suture Zone into the mantle transition zone, Earth Planet. Sci. Lett., 363, 73-87, 2013.

Koch, M.: A numerical study on the determination of the 3-D structure of the lithosphere by linear and non-linear inversion of teleseismic travel times, Geophys, J. R. Astron. Soc., 80, 73-93, 1985.

Koulakov, I., Kaban, M. K., Tesauro M., and Cloetingh S.: P- and $\mathrm{S}$-velocity anomalies in the upper mantle beneath Europe from tomographic inversion of ISC data, Geophys. J. Int., 179, 345366, 2009.

Legendre, C. P., Meier, T., Lebedev, S., Friederich, W., and ViereckGötte, L.: A shear wave velocity model of the European upper mantle from automated inversion of seismic shear and surface waveforms, Geophys. J. Int., 191, 282-304, 2012.

Majdański, M.: The structure of the crust in TESZ area by kriging interpolation. Acta Geophysica, 60, 59-75, 2012.

Majorowicz, J. A., Čermak, V., Šafanda, J., Krzywiec, P.,Wróblewska, M., Guterch, A., and Grad, M.: Heat flow models across the Trans-European Suture Zone in the area of the POLONAISE'97 seismic experiment, Phys. Chem. Earth, 28, 375-391, 2003.
Malinowski, M., Grad, M., Guterch, A., and CELEBRATION 2000 Working Group: Three-dimensional seismic modelling of the crustal structure between East European Craton and the Carpathians in SE Poland based on CELEBRATION 2000 data, Geophys. J. Int., 173, 546-565, 2008.

Menke, W.: Geophysical data analysis: Discrete inverse theory, Academic Press Inc., Orlando, Fl., 260 pp., 1984.

Motuza, G.: Structure and formation of the crystalline crust in Lithuania. Mineralogical Society of Poland, Special Papers, 26, 67-79, 2005.

Motuza, G. and Staškus, V.: Seniausios Lietuvos uolienos. Geologijos akiračiai, ISSN 1392-0006, 3/4, 41-47, 2009.

Motuza, G., Nasedkin, V., Jacyna, J., and Korabliova, L.: The structure of the upper part of the lithosphere along the Eurobridge profile in Lithuania. Lithuanian Geological Survey Annual Report, Vilnius, 54-56, 2000.

Nolet, G. and Zielhuis, A.: Low S velocities under the TornquistTeisseyre zone: evidence from water injection into the transition zone by subduction, J. Geophys. Res., 99, 15813-15820, 1994.

Pharaoh, T. C. and TESZ Project Core Group: EUROPROBE TransEuropean Suture Zone project, British Geological Survey, EUROPROBE News 12, June 2000, 2000.

Plomerova, J. and Babuska, V.: Seismic anisotropy of the lithosphere around the Trans-European suture zone (TESZ) based on teleseismic body-wave data of the TOR experiment, Tectonophysics, 360, 89-114, 2002.

Rasteniene, V., Sliaupa, S., and Skridlaite, G.: The geothermal field of Lithuania. Proceedings of the international conference "The Earth's Thermal Field and Related Research Methods", Moscow, 230-233, 1998.

Rämö, O. T., Huhma, H., and Kirs, J.: Radiogenic Isotopes of the Estonian and Latvian Rapakivi Granite Suite: New Data from the Concealed Precambrian of the East European Craton, Precambrian Res., 79, 209-226, 1996.

Taran, L. N. and Bogdanova, S. V.: The Fennoscandia-Sarmatia junction in Belarus: new inferences from a PT-study, Tectonophysics, 339, 193-214, 2001.

Thomson, C. J. and Gubbins, D.: Three-dimensional lithospheric modelling at NORSAR: linearity of the method and amplitude variations from the anomalies, Geophys. J. R. Astron. Soc., 71, 1-36, 1982.

Sandoval, S., Kissling, E., Ansorge, J., and the SVEKALAPKO Seismic Tomography Working Group: High-resolution body wave tomography beneath the SVEKALAPKO array: II. Anomalous upper mantle structure beneath the central Baltic Shield, Geophys. J. Int., 157, 200-214, 2004.

Sandoval Castano, S.: The Lithosphere-Asthenosphere System beneath Fennoscandia (Baltic Shield) by Body-wave Tomography, A dissertation submitted to the Swiss Federal Institute of Technology Zurich, 2002.

Shomali, Z. H., Roberts, R. G., Pedersen, L. B., and the TOR Working Group: Lithospheric structure of the Tornquist Zone resolved by nonlinear $\mathrm{P}$ and $\mathrm{S}$ teleseismic tomography along the TOR array, Tectonophysics, 416, 133-149, 2006.

Skobelev, V. M.: Petrocheminstry and geochronology of the Precambrian formations of the north-western region of the Ukrainian Shield, Naukova Durnka, Kiev, 140 pp., 1987.

Sroda, P. and the POLCRUST and PASSEQ Working Groups: Seismic anisotropy and deformations of the TESZ lithosphere near 
the East European Craton margin in SE Poland at various scales and depths. EGU General Assembly 2014, Geophys. Res. Abstr., 16, EGU2014-6463-1, 2014.

Steck, L. K. and Prothero, W. A. J.: A 3-D raytracer for teleseismic body-wave arrival times, Bull. Seism. Soc. Am., 81, 1332-1339, 1991.

Vecsey, L., Plomerova, J., Babuska, V., and PASSEQ Working Group: Structure of the mantle lithosphere around the TESZ from the East European Craton to the Variscan Belt. EGU General Assembly 2013, Geophys. Res. Abstr., 15, EGU2013-3133, 2013.

Voss, P., Mosegaard, K., Gregersen, S., and TOR Working Group: The Tornquist Zone, a north east inclining lithospheric transition at the south western margin of the Baltic Shield: Revealed through a nonlinear teleseismic tomographic inversion, Tectonophysics, 416, 151-166, 2006.

Wessel, P. and Smith, W.: Free software helps map and display data, EOS, Trans. Am. Union, 72, 441 pp., 1991.

Wilde-Piórko, M., Geissler, W.H., Plomerová, J., Grad, M., Babuška, V., Brückl, E., Čyžienè, J., Czuba, W., Eengland, R., Gaczyński, E., Gazdova, R., Gregersen, S., Guterch, A., Hanka, W., Hegedűs, E., Heuer, B., Jedlička, P., Lazauskienė, J., Randy Keller, G., Kind, R., Klinge, K., Kolinsky, P., Komminaho, K., Kozlovskaya, E., Krúger, F., Larsen, T., Majdański, M., Málek, J., Motuza, G., Novotný, O., Pietrasiak, R., Plenefish, Th., Rǔžek, B., Šliaupa, S., Środa, P., Świeczak, M., Tiira, T., Voss, P., and Wiejacz, P.: PASSEQ 2006-2008: PASsive Seismic Experiment in Trans-European Suture Zone, Stud. Geophys. Geod., 52, 439448, 2008.
Wilde-Piórko, M., Świeczak, M., Grad, M., and Majdański, M.: Integrated seismic model of the crust and upper mantle of the Trans-European Suture zone between the Precambrian craton and Phanerozoic terranes in Central Europe, Tectonophysics, 481, 108-115, 2010.

Wüstefeld, A., Bokelmann, G., and Barruol, G.: Evidence for ancient lithospheric deformation in the East European Craton based on mantle seismic anisotropy and crustal magnetics, Tectonophysics, 481, 16-28, 2010.

Yliniemi, J., Kozlovskaya, E., Hjelt, S. E., Komminaho, K., and Ushakov, A.: Structure of the crust and uppermost mantle beneath southern Finland revealed by analysis of local events registered by the SVEKALAPKO seismic array, Tectonophysics, 394, 41-67, 2004. 